\title{
DOSTĘPNOŚĆ I JAKOŚĆ DANYCH STATYSTYCZNYCH, NIEZBĘDNYCH DO BUDOWANIA STRATEGII GOSPODARKI NISKOEMISYJNEJ W JEDNOSTKACH SAMORZĄDU TERYTORIALNEGO
}

\begin{abstract}
Streszczenie
Wdrażanie gospodarki niskoemisyjnej w Polsce wynika z potrzeby dokonania redukcji emisji gazów cieplarnianych i innych zanieczyszczeń powietrza we wszystkich obszarach gospodarki. Największe nadzieje na poprawę jakości powietrza wiąże się ze zmniejszaniem udziału węgla w wytwarzaniu energii, wprowadzaniem innowacyjnych technologii i poprawą efektywności energetycznej. W gestii władz jednostek samorządu terytorialnego jest stworzenie odpowiednich strategii działania, które służyłyby osiaganiu tych celów, zwłaszcza w odniesieniu do budownictwa i transportu publicznego. Celem artykułu jest ocena stanu monitoringu środowiska w zakresie zanieczyszczeń powietrza pochodzących z tych sektorów, jak również danych statystycznych pod kątem ich przydatności do realizacji działań w zakresie gospodarki niskoemisyjnej na poziomie lokalnym.
\end{abstract}

Słowa kluczowe: gospodarka niskoemisyjna, dane statystyczne, jednostki samorządu terytorialnego

\section{AVAILABILITY AND QUALITY OF STATISTICAL DATA INDISPENSABLE FOR LOW-EMISSION DEVELOPMENT STRATEGIES IN LOCAL GOVERNMENT UNITS}

\section{Summary}

Implementation of low-emission economy in Poland stems from the need to reduce the amount greenhouse gases and other air pollutants in all areas of the economy. The highest expectations for improving air quality are associated with a reduction in the use of carbon for energy production, implementation of new technologies and enhancement of energy efficiency. It is local governments that have the responsibility for developing adequate strategies which would help achieve these goals, especially in the fields of construction and public transport. The purpose of this paper is to assess the monitoring of air pollution generated by enterprises from the above-mentioned sectors and to analyse relevant statistical data in terms of their usefulness in implementing low-emission strategy measures on a local level.

Key words: low-emission economy, statistical data, local government units

\section{Wstęp}

Koncepcja gospodarki niskoemisyjnej wywodzi się z, przyjętej w 1992 roku w Rio de Janeiro, Ramowej konwencï Narodów Zjednoczonych w sprawie zmian klimatu. Postulat ogra-

1 dr hab. Małgorzata Burchard-Dziubińska, Wydział Ekonomiczno-Socjologiczny, Uniwersytet Łódzki; e-mail: malbur@uni.lodz.pl. 
niczenia emisji gazów cieplarnianych w celu ochrony klimatu powiązano z rozwojem gospodarki niskowęglowej, co jest utożsamiane z budową strategii niskoemisyjnego rozwoju (low-emission development strategies LEDS). Choć formalnie nie sformułowano wówczas żadnej definicji LEDS, terminu tego używa się do opisania, związanych z odległa przyszłościa, planów/strategii rozwoju, którym będzie towarzyszyć ograniczenie emisji $\mathrm{CO}_{2}$ i innych gazów cieplarnianych. Początkowo koncepcja LEDS miała zachęcać kraje rozwijające się do udziału w negocjacjach w sprawie ochrony klimatu, rozumianych jako „miękka” alternatywa dla dobrowolnych lub obligatoryjnych celów redukcji gazów cieplarnianych. W 2008 roku Unia Europejska wystąpiła z inicjatywą wzmocnienia działań, podkreślając, że informacje o planowanym wejściu na ścieżkę niskoemisyjnego rozwoju pomoga przekonać międzynarodową opinię publiczna do potrzeby rozwoju globalnej współpracy na rzecz ochrony klimatu. Odwołania do koncepcji LEDS zostały zawarte w dokumentach końcowych z kolejnych szczytów klimatycznych: w Porozumieniu Kopenbaskim (2009 rok) i w Porozumieniu z. Cancun (2010 rok), chociaż wypada w tym miejscu odnotować, że nie wywarło to większego wpływu na dalszy przebieg negocjacji w sprawie ochrony klimatu. Jednak nie oznacza to, że zupełnie nie interesowano się ta problematyka. Niewatpliwie, liderem w propagowaniu rozwoju gospodarki niskoemisyjnej i efektywnie wykorzystującej zasoby pozostaje Unia Europejska. Wyraźnie wynika to z przyjętych w ostatnich latach dokumentów: Pakietu klimatyczno-energetycznego z. 2009 roku, Strategii Europa 2020, Planu działania prowadzacego do przejścia na konkurencyjna gospodarke niskoemisyjna do 2050 roku. Kraje członkowskie Unii Europejskiej wykazują bardzo zróżnicowane poparcie dla rozwoju gospodarki niskoemisyjnej / niskowęglowej, co w dużej mierze wynika ze specyficznych dla nich „miksów” energetycznych, poziomu rozwoju gospodarczego i zaawansowania w dziedzinie opracowywania i wdrażania ekoinnowacji. W artykule celem rozważań jest ocena dostępności i jakości danych niezbędnych do opracowywania strategii niskoemisyjnego rozwoju polskich gmin. Zebrane doświadczenia eksperckie pozwalają wyciagnąć ogólny wniosek, że brak odpowiednich danych statystycznych oraz wysokie koszty związane $z$ ich pozyskaniem, przeszkoleniem odpowiednich kadr lub zatrudnieniem zewnętrznych audytorów stanowią poważną przeszkodę w budowie strategii gospodarki niskoemisyjnej przez jednostki samorządów terytorialnych (JST) w Polsce. Wiąże się to z niską świadomością energetyczną Polaków i brakiem odpowiednich nawyków w korzystaniu z energii zarówno w życiu codziennym, jak i planowaniu długookresowym [Polacy o oszcrzedzanin energii, dokument elektroniczny, tryb dostępu: http://6paliwo.pl/wp-content/ uploads/2012/02/6paliwo-raport-1.pdf, data wejścia: 06.06.2014]. Wprawdzie w Unii Europejskiej poszukiwanie dróg niskoemisyjnego rozwoju na poziomie JST stało się w ostatnich latach dość popularne, w Polsce nadal należy do rzadkości, mimo istnienia obowiązków wynikających z przepisów prawnych: ustawy Prawo energetyczne [Ustawa z dnia 10 kwietnia 1997 roku Prawo energetyczne, tekst jednolity, Dz.U. 2008, Nr 89, poz. 625], która nakłada obowiązek sporządzania dokumentów planistycznych z zakresu gospodarowania energia oraz ustawy o efektywności energetycznej [Ustawa z dnia 15 kwietnia 2011 roku o efektywności energetycznej, Dz. U., Nr 94, poz. 551] zobowiązującej samorządy do spełnienia określonych standardów efektywności energetycznej. Pojawiające się inicjatywy dobrowolne, takie jak przykładowo Porozumie- 
nie Burmistrzów SEAP, także tylko w niewielkim stopniu wspierają politykę klimatyczną i energetyczną na poziomie lokalnym.

Do analiz wykorzystano informacje zawarte $\mathrm{w}$ dokumentach publikowanych na stronach internetowych JST, jak również dane GUS i BDL oraz wyniki zawarte w Diagnozie przeprowadzonej w zwiqz ku z.praygotowaniem Strategii Rožwoju Łódzkiego Obszaru Metropolitalnego 2020+ [Dokument elektroniczny, tryb dostępu: http://www.uml.lodz.pl/miasto/strate gia/strategia_rozwoju_lodzkiego_obszaru_metropolitalnego, data wejścia: 05.06.2014].

\section{Definiowanie gospodarki niskoemisyjnej}

Zgodnie z definicja podawana przez Krajowa Agencję Poszanowania Energii: gospodarka niskoemisyjna to taka driatalność čztowieka, która praynosi zysk inwestorom, warrost gospodarcyy krajowi $i$ znaczna redukcje emisji $\mathrm{CO}_{2}$. Jednak z praktyki wynika jasno, że działania w tym kierunku nie stały się dotąd naturalnym biznesowym wyborem, a zmiany w prawie na poziomie międzynarodowym i krajowym muszą być wspierane przez systemy różnych zachęt, aby rzeczywiście wpłynąć na zachowanie podmiotów gospodarczych. Typowe kalkulacje finansowe zwykle nie obejmują analizy kosztów i korzyści zewnętrznych, pomijają lub niedoszacowują wartości takich kategorii, jak zdrowie środowiskowe i usługi ekosystemów. W przyjętych w sierpniu 2011 roku Założeniach narodowego planu rožwoju gospodarki niskoemisyjnej brak jest typowej definicji tego typu gospodarki. Może to świadczyć o pewnych problemach związanych ze zdefiniowaniem gospodarki niskoemisyjnej na potrzeby realizacji polityki rozwoju w Polsce. Podkreślono natomiast, że przestanienie gospodarki na gospodarke niskoemisyjna a tym samym ograniczenie emisji gazón cieplarnianych $i$ innych substancii unaża sie, nie tylko za kluczony krok w kiernnku zapewnienia stabilnego środowiska, lecz takize element dlugofalowego zrównoważonego rožwoju [Zatożenia narodowego planu..., 2011, s. 6]. Istota programu jest zapewnienie korzyści ekonomicznych, społecznych i przyrodniczych (zgodnie z konstytucyjna zasadą zrównoważonego rozwoju), płynących z działań zmniejszających emisje, osiaganych m.in. przez: wzrost innowacyjności i wdrożenie nowych technologii, zmniejszenie energochłonności, tworzenie nowych miejsc pracy, a w konsekwencji sprzyjających wzrostowi konkurencyjności gospodarki. W praktyce oznacza to koncentrację na celu głównym: Rozwoju gospodarki niskoemisyjnej prsy zapewnieniu zrównoważonego rožroju kraju i sześsiu celach szczegótonych:

1. Rozwoju niskoemisyjnych źródet energii;

2. Poprawie efektynności energetycznej;

3. Poprawie efektywności gospodarowania surowcami i materiatami;

4. Rozwoju i wykorzystaniu technologii niskoemisyjnych;

5. Zapobieganiu powstawaniu oraz poprawie efektywności gospodarowania odpadami;

6. Promocji nowych wzorców konsumpcii [Zatożenia narodowego planu..., 2011, s. 6].

Opracowanie Narodowego Programu Rozwoju Gospodarki Niskoemisyjnej (NPRGN) łączy się z koniecznością dokonania redukcji emisji gazów cieplarnianych $i$ innych substancji wprowadzanych do powietrza we wszystkich obszarach gospodarki. Osiagnięcie efektu redukcyjnego będzie powiazzane $z$ racjonalnym wydatkowaniem środków. 
$\mathrm{Na}$ potrzeby dalszych analiz przyjęto definicję gospodarki niskoemisyjnej, zawarta w podręczniku dla regionów wydanym przez INTERREG IVC. Brzmi ona następujaco: Gospodarka niskoemisyjna to gospodarka, której wzrost osiaga sie w wyniku integracii wszystkich aspektón gospodarki wokót niskoemisymych technologii i praktyk, wydajnych rozwiazan energetycznych, crystej odnawialnej energii i proekologicznych innowacji technologicznych. W ramach takiej gospodarki w sposób efektywny zuizywa sie / lub uytwwarza energie i materialy, a takize usuwa badź odzyskuje odpady metodami minimalizujacymi emisje gazón cieplarnianych. Dwutlenek wegla $\left(\mathrm{CO}_{2}\right)$ to najwaizniejsyy gaz cieplamiany pod wagledem ilości, natomiast pozostate poziomy emisji gazón cieplarnianych pręeliczono na ekwiwalent dwutlenku wegla $\left(\mathrm{CO}_{2}\right.$ eq). Wobec ponyisszego terminologia niskoemisyjna obejmuje catkowita ilość garón cieplarnianych [Budowa..., dokument elektroniczny, tryb dostępu: http://documents.rec.org/publications/RSC_BuildingLow_carbonEconomy_PL_Dec 2011.pdf, data wejścia: 15.01.2014].

\section{Metodologia pomiaru emisji}

Z treści cytowanej definicji wynika, że przedmiotem zainteresowania jest redukcja całkowitej emisji gazów cieplarnianych, którą ewidencjonuje się po przeliczeniu jej na dwutlenek węgla o współczynniku globalnego ocieplenia równym jeden. Inne gazy cieplarniane, brane ewentualnie pod uwagę, mają współczynniki globalnego ocieplenia wyższe - od 21 razy w przypadku metanu do $22800 \mathrm{w}$ przypadku sześciofluorku siarki. Współczynnik globalnego ocieplenia (GWP) jest obliczany na podstawie skutków oddziaływania jednego kilograma danego gazu na ocieplenie klimatu w ciagu 100 lat w porównaniu z oddziaływaniem jednego kilograma $\mathrm{CO}_{2}$. Prowadzone na całym świecie badania dowodzą znaczącego wpływu kolejnych gazów na klimat. Dotyczy to tzw. gazów przemysłowych, będących wytworem człowieka. Według ostatnich doniesień naukowych, takie oddziaływanie wykazano dla perfluorotributyloaminy (PFTBA), która należy do tzw. perfluorozwiązków. Wyniki prac związane z gazem PFTBA zostały przedstawione w Geophysical Research Letters Issue [Hong, i in. 2013] w listopadzie 2013 roku i należy spodziewać się kolejnych doniesień na temat innych gazów. Tabela 1. zawiera współczynniki globalnego ocieplenia według nomenklatury zalecanej przez Intergovernmental Panel on Climate Change (IPCC).

Przystępując do pomiarów emisji wyjściowych i śledzenia ich zmian, trzeba zdecydować się na postępowanie stosownie do określonej procedury. Stąd warte uwagi są dwie: zgodna ze standardami wyznaczonymi przez IPCC lub oparta na cyklu życia produktu. 
TABELA 1. Współczynniki globalnego ocieplenia wybranych gazów w horyzoncie czasowym 100 lat

\begin{tabular}{|l|c|c|}
\hline \multicolumn{1}{|c|}{ Nazwa gazu } & $\begin{array}{c}\text { Czas trwania w atmosferze } \\
\text { w latach }\end{array}$ & $\begin{array}{c}\text { Współczynnik globalnego } \\
\text { ocieplenia GPW }\end{array}$ \\
\hline Dwutlenek węgla $\left(\mathrm{CO}_{2}\right)$ & 7 & 1 \\
Metan $\left(\mathrm{CH}_{4}\right)$ & 12 & 21 \\
Podtlenek azotu $\left(\mathrm{N}_{2} \mathrm{O}\right)$ & 144 & 310 \\
Czterofluorek węgla $\left(\mathrm{CF}_{4}\right)$ & 50000 & 5700 \\
Sześciofluorek siarki $\left(\mathrm{SF}_{6}\right)$ & 3200 & 22800 \\
Halon-1211 $\left(\mathrm{CF}_{2} \mathrm{BrCl}\right)$ & 11 & 1300 \\
Halon-1301 $\left(\mathrm{CF}_{3} \mathrm{Br}\right)$ & 65 & 6900 \\
\hline
\end{tabular}

Źródło: opracowanie własne na podstawie literatury.

Pierwsza z nich polega na określeniu całkowitej emisji $\mathrm{CO}_{2}$ pochodzącej z pomiaru końcowego zużycia energii. Należy wziąć pod uwagę emisje bezpośrednie ze spalania paliw w: budynkach, instalacjach i transporcie oraz emisje pośrednie, towarzyszące produkcji energii elektrycznej, ciepła i chłodu wykorzystywanej przez mieszkańców. Standardowe wskaźniki emisji opierają się na zawartości węgla w poszczególnych paliwach i są wykorzystywane do inwentaryzacji gazów cieplamianych przez strony Ramowej konwengi Narodów Zjednoczonych w spranie zmian klimatu. Jest to niewatpliwa zaleta tej metody, gdyż Polska ma już doświadczenie w jej stosowaniu. Po pierwsze, jako strona konwencji klimatycznej, po drugie, prowadząc ewidencje na potrzeby monitorowania postępów w realizacji celów pakietu klimatyczno-energetycznego Unii Europejskiej. Ewidencjonuje się $\mathrm{CO}_{2}$, zaś $\mathrm{CH}_{4}$ i $\mathrm{N}_{2} \mathrm{O}$ można pominąć. Emisje $\mathrm{CO}_{2}$, powstające w wyniku spalania biomasy i biopaliw wytwarzanych w zrównoważony sposób oraz emisje związane z wykorzystaniem certyfikowanej zielonej energii elektrycznej, sa traktowane jako zerowe. Intergovernmental Panel on Climate Change co jakiś czas publikuje wytyczne, w których podaje aktualne wartości wskaźników.

Druga metoda - LCA (Life Cycle Assessment) - jest oparta na analizie całego cyklu życia poszczególnych nośników energii. Jest znacznie trudniejsza w stosowaniu, ze względu na konieczność uwzględnienia także emisji powstałych na wszystkich etapach łańcucha dostaw, tzn. emisji zwiazzanych z pozyskiwaniem surowców, ich transportem i przeróbką. Oznacza to konieczność brania pod uwagę również emisji powstałych poza granicami obszaru, na którym są wykorzystywane paliwa. Przy takim podejściu emisje, powstające w wyniku spalania biomasy i biopaliw oraz całkowitej zielonej energii elektrycznej, ujmuje się jako wyższe od zera. Za zasadne uważa się równocześnie uwzględnianie emisji innych gazów cieplarnianych. Metodologia ta jest wykorzystywana do wyznaczania śladu węglowego. Stanowiła podstawę przy opracowaniu: strategii tematycznej w sprawie zrównoważonego wykorzystania zasobów naturalnych oraz zapobiegania powstawaniu odpadów i ich recyklingu [Komunikat Komisji dla Rady..., 2005], Dyrektywy w sprawie eko-projektowania [Dyrektywa Parlamentu Europejskiego..., 2009] i Rozporzqdzenia w sprawie oznakowania ekologicrnego. Jednocze- 
śnie znalazła zastosowanie w normie ISO 14040 [Norma ISO 14040:2006...]. Niewątpliwą zaletą metody LCA jest również możliwość odzwierciedlenia całkowitego oddziaływania na środowisko paliw lub energii, które powstały poza miejscem ich wykorzystywania.

Obie wymienione metody zostały już dobrze opisane w literaturze i istnieją dla nich opracowane narzędzia umożliwiające sporządzanie inwentaryzacji na szczeblu lokalnym. Do władz samorządowych należy decyzja, czy przedmiotem ewidencji będzie emisja $\mathrm{CO}_{2}$ czy $\mathrm{CO}_{2}$ eq. Wybór metody powinien być dokładnie przemyślany, dostosowany do lokalnej specyfiki i możliwości organizacyjnych. Jest to bardzo ważne, gdyż tylko prawidłowo przeprowadzona ewidencja emisji może na danym terenie stanowić podstawę do budowy strategii gospodarki niskoemisyjnej. Warto zwrócić uwagę np. na takie kwestie, jak:

- $\quad$ istotność emisji $\mathrm{CH}_{4}$ i $\mathrm{N}_{2} \mathrm{O}$ związanych z funkcjonowaniem na terenie JST składowisk odpadów, oczyszczalni ścieków, transportu;

- $\quad$ wykorzystywanie paliw i ciepła pochodzących ze źródeł odnawialnych;

- $\quad$ pochodzenie energii elektrycznej (z sieci krajowej lub z produkcji lokalnej);

- zakup certyfikowanej zielonej energii przez samorząd lokalny;

- produkcja ciepła/chłodu jako towaru dostarczanego użytkownikom końcowym na terenie JST;

- $\quad$ kogeneracja, czyli łączna produkcja energii elektrycznej i cieplnej wykorzystywanej na ternie JST.

Wymienione kategorie zagadnień problemowych świadczą o złożoności procesu ewidencjonowania emisji gazów cieplarnianych na terenie poszczególnych JST. Choć formalnie można ograniczyć działania do obiektów, które są pod bezpośrednim zarządem władz lokalnych, to szersze spojrzenie na problem emisji może przynieść zaskakująco dobre efekty w postaci poprawy jakości powietrza, zwłaszcza na terenach zurbanizowanych o zwartej zabudowie, gdzie głównie w sezonie grzewczym poważnym zagrożeniem jest smog.

Równocześnie można wykorzystywać inne opracowania, takie jak np. Międżynarodowy Protokót Analizy Gazón Cieplarnianych z Obszarón Miasta/Gminy (IEAP), który zawiera wskaźniki emisji specyficzne dla poszczególnych krajów.

\section{Przedmiot i zakres analizy emisji w JST}

Zwrot ku rozwojowi niskoemisyjnemu, opartemu na efektywności energetycznej, energii odnawialnej i zrównoważonej produkcji i konsumpcji, oznacza dla samorządów konieczność przeprowadzenia rachunków długookresowych kosztów i korzyści różnych działań inwestycyjnych lub ich zaniechania - uwzględniających także koszty i korzyści społeczne i przyrodnicze - w odniesieniu do obszarów i obiektów, które są w gestii władz samorządowych. Na poziomie gmin przede wszystkim chodzi o:

- $\quad$ wskazanie podmiotów - współuczestnictwo podmiotów będących producentami i/lub odbiorcami energii, ze szczególnym uwzględnieniem działań w sektorze publicznym; 
- $\quad$ wskazanie działań - skoncentrowanie się na działaniach niskoemisyjnych i efektywnie wykorzystujących zasoby w perspektywie do 2020 roku, z wyszczególnieniem zadań inwestycyjnych;

- zachowanie spójności z innymi planami/dokumentami: własnymi, regionalnymi, krajowymi i Unii Europejskiej.

Zadania inwestycyjne związane $\mathrm{z}$ gospodarka niskoemisyjną w gminach dotycza głównie:

- różnych typów budynków (nowych, poddawanych renowacji, użyteczności publicznej, historycznych);

- oświetlenia budynków mieszkalnych i użytkowych oraz oświetlenia elementów infrastruktury;

- ogrzewania/chłodzenia sieciowego;

- urządzeń biurowych;

- produkcji energii elektrycznej i cieplnej (profilu energetycznego gminy);

- transportu;

- gospodarki odpadami.

Zadania nieinwestycyjne na poziomie gmin moga na przykład zawierać: planowanie miejskie, strategie komunikacyjne, promowanie gospodarki niskoemisyjnej wśród mieszkańców i przedsiębiorców, zamówienia publiczne itd.

Przykładowo, poradnik pt.: Jak opracować plan działań na rzecz zrónnowažonej energii (SEAP), opracowany na potrzeby Porozumienia Burmistrzów dla zrównoważonej gospodarki energetycznej na szczeblu lokalnym, przy dokonywaniu oceny sytuacji wyjściowej rekomenduje objęcie przedmiotem zainteresowania następujących obszarów i aspektów [SEAP, 2010]:

1. Struktura zużycia energii i emisja $\mathrm{CO}_{2}-\mathrm{w}$ zakresie poziomu i ewolucji zużycia energii $\mathrm{i}$ emisji $\mathrm{CO}_{2} \mathrm{z}$ podziałem na sektory oraz nośniki energii. Wielkości należy podać w wartościach bezwzględnych i per capita;

2. Odnawialne źródła energii - w zakresie: typologii istniejących instalacji służących do produkcji energii ze źródeł odnawialnych; wielkości produkcji energii ze źródeł odnawialnych i trendów w tym zakresie; wykorzystania biomasy pochodzenia rolniczego i leśnego jako odnawialnego źródła energii; występowania upraw bioenergetycznych; stopnia zaspokojenia zapotrzebowania na odnawialne źródła energii przy wykorzystaniu lokalnie dostępnych zasobów; potencjału odnawialnych źródeł energii: energii słonecznej, energii wiatru, energii wody, biomasy $i$ innych;

3. Zużycie energii i zarządzanie energia w sektorze komunalnym - w zakresie: poziomu zużycia energii i jego zmiany $\mathrm{w}$ sektorze komunalnym $\mathrm{z}$ podziałem na podsektory (budynki i urządzenia, oświetlenie publiczne, gospodarka odpadami, gospodarka ściekami itp.) oraz nośniki energii; oceny efektywności wykorzystania energii w budynkach i urządzeniach przy wykorzystaniu odpowiednich wskaźników (na przykład: $\mathrm{kWh} / \mathrm{m}^{2}, \mathrm{kWh} / \mathrm{m}^{2}$ - użytkownik, $\mathrm{kWh} / \mathrm{m}^{2} \mathrm{z}$ podziałem na poszczególne godziny), co pozwoli zidentyfikować budynki, w których istnieje największy potencjał poprawy efektywności ener- 
getycznej; charakterystyki budynków i urządzeń komunalnych, cechujących się najwyższym zużyciem energii (analiza kluczowych zmiennych, takich jak na przykład: typ konstrukcji, rodzaj ogrzewania, rodzaj klimatyzacji i wentylacji, rodzaj kuchni, sposób utrzymania, wykorzystanie energii słonecznej do podgrzewania wody, wdrażanie najlepszych praktyk); oszacowania rodzajów lamp i opraw oświetleniowych oraz innych kwestii zwiazanych z wykorzystaniem energii w oświetleniu publicznym; poziomu i adekwatności zarządzania energia $\mathrm{w}$ budynkach/instalacjach publicznych i oświetleniu publicznym (w tym ewidencjonowanie zużycia energii, wykonywanie audytów energetycznych); istniejacych inicjatyw mających na celu ograniczenie zużycia energii i poprawę efektywności energetycznej; identyfikacji potencjału oszczędności energii i poprawy efektywności energetycznej w: budynkach, instalacjach i oświetleniu publicznym;

4. Zużycie energii przez pojazdy wchodzace w skład taboru gminnego - w zakresie: składu taboru gminnego (pojazdy własne i wykonujące usługi zlecone przez gminę) oraz składu taboru komunikacji miejskiej i rocznego zużycia energii; poziomu zarządzania wykorzystaniem energii przez pojazdy wchodzące w skład taboru gminnego i taboru komunikacji miejskiej; istniejących inicjatyw majacych na celu ograniczenie zużycia energii; identyfikacji potencjału poprawy efektywności energetycznej;

5. Infrastruktura energetyczna - w zakresie: istnienia zakładów produkujących energię elektryczną oraz ciepło; charakterystyki sieci dystrybucji energii elektrycznej i gazu, jak również miejskiej sieci ciepłowniczej; istniejących inicjatywy mających na celu poprawę efektywności energetycznej zakładów energetycznych i sieci dystrybucji oraz ich dotychczasowe rezultaty; identyfikacji potencjału poprawy efektywności energetycznej;

6. Budynki - w zakresie typologii istniejących zasobów budowlanych ze względu na: wykorzystanie (cele mieszkaniowe, handlowe, usługowe, socjalne), wiek, ocieplenie i inne elementy charakterystyki energetycznej, zużycie energii $i$ trendy w tym zakresie, status ochronny, stopień renowacji itd.; charakterystyki ogólnej i energetycznej nowych i remontowanych budynków; minimalnych wymagań prawnych w zakresie standardów energetycznych, jakie muszą spełniać nowe oraz remontowane budynki i ich odzwierciedlenie w praktyce; istnienia inicjatyw mających na celu promocję efektywności energetycznej i wykorzystania odnawialnych źródeł energii w różnych typach budynków i osiagniętych rezultatów;

7. Przemysł - w zakresie: znaczenia sektora przemysłu w bilansie energetycznym i bilansie emisji $\mathrm{CO}_{2}$; istnienia publicznych i prywatnych inicjatyw mających na celu promocję oszczędzania energii i poprawę efektywności energetycznej w przemyśle i ich głównych rezultatów; stopnia integracji zarządzania energia/emisjami dwutlenku węgla w przedsiębiorstwach przemysłowych; możliwości ograniczenia zużycia energii i poprawy efektywności energetycznej w przemyśle; 
8. Transport i mobilność - w zakresie: charakterystyki potrzeb i wymogów w odniesieniu do mobilności i środków transportu wraz z podaniem wzorcowych przykładów i głównych trendów; korzystania z transportu publicznego; występowania problemów z natężeniem ruchu i/lub jakością powietrza; zaspokojenia potrzeb dotyczących dostępności traktów pieszych i ścieżek rowerowych; zarządzania ruchem i planowania mobilności; inicjatyw mających na celu promocję: transportu publicznego, ruchu rowerowego oraz ruchu pieszego;

9. Planowanie miejskie $-\mathrm{w}$ zakresie charakterystyki istniejących i projektowanych „przestrzeni miejskich”, w tym: informacji związanych z mobilnościa i gęstością zaludnienia, wykorzystania (cele mieszkaniowe, działalność gospodarcza, zakupy itd.) wraz z opisem budynków; stopnia rozproszenia i zagęszczenia rozwoju obszarów miejskich; dostępności i lokalizacji podstawowych usług i urządzeń infrastruktury miejskiej (w tym: placówek edukacyjnych, ośrodków zdrowia, centrów kultury, obiektów handlowych, przestrzeni zielonych itd.) oraz ich bliskości do głównych skupisk ludności; stopnia, w jakim kryteria efektywności energetycznej są uwzględniane w planowaniu rozwoju miasta; stopnia, w jakim kryteria zrównoważonej mobilności są ujmowane w planowaniu miejskim oraz adekwatności wymienionych kryteriów;

10. Zamówienia publiczne $-\mathrm{w}$ zakresie: istnienia konkretnego zobowiązania politycznego dotyczacego zielonych zamówień publicznych; stopnia, do jakiego sa stosowane $\mathrm{w}$ procesie zamówień publicznych kryteria związane $\mathrm{z}$ energia i ochroną klimatu; istnienia określonych procedur oraz wykorzystania poszczególnych narzędzi (np. wyznaczanie śladu węglowego);

11. Świadomość - w zakresie: postępu w realizacji działań mających na celu komunikację z mieszkańcami i lokalnymi interesariuszami oraz podniesienia ich świadomości w odniesieniu do efektywności energetycznej oraz adekwatności wymienionych działań; poziomu świadomości mieszkańców i lokalnych interesariuszy obejmującego efektywność energetyczną i potencjał oszczędności energii; istnienia inicjatyw i narzędzi zmierzających do ułatwienia mieszkańcom i lokalnym interesariuszom zaangażowania się w proces opracowania i wdrażania planów klimatyczno-energetycznych, realizowanych przez władze lokalne;

12. Umiejętności i wiedza specjalistyczna - w zakresie posiadania przez pracowników miasta/gminy odpowiednich umiejętności i wiedzy specjalistycznej, w tym: wiedzy technicznej (np. w obszarze: efektywności energetycznej, wykorzystania odnawialnych źródeł energii, efektywnego transportu), wiedzy dotyczącej: zarządzania projektami, zarządzania danymi, zarządzania finansami i opracowania projektów inwestycyjnych, umiejętności komunikacji, wiedzy w ramach zielonych zamówień publicznych itd.

Tylko prawidłowa diagnoza sytuacji wyjściowej może stanowić podstawę dalszego działania. Wymienione obszary, rekomendowane do objęcia analiza, pozwola wyłonić te spośród nich, które okażą się najistotniejsze do uzyskania przyszłej poprawy sytuacji na terenie JST. 
Badanie, przeprowadzone w listopadzie 2013 roku, w gminach na potrzeby opracowania Strategii Rozwoju Lódzkiego Obszaru Metropolitalnego 2020+, było podstawa do określenia gotowości i zaawansowania prac nad budową gospodarki niskoemisyjnej na tym terenie. Pytania sformułowane w kwestionariuszu zostały skierowane do wszystkich 28 gmin wchodzących w skład 5 powiatów tworzących $\mathrm{LOM}$. Biorąc pod uwagę fakt, że rozwój gospodarki niskoemisyjnej będzie w perspektywie 2020+ istotnym kierunkiem działania, dla którego zostało przewidziane znaczne wsparcie finansowe ze środków Unii Europejskiej, diagnoza aktualnego stanu wiedzy i przygotowania gmin do realizacji zadań na rzecz gospodarki niskoemisyjnej stanowiła bardzo istotny element prac nad strategia. Gminy miały odpowiedzieć TAK lub NIE na trzy następujące pytania: Czy istnieje rozeznanie co do poziomu i źródeł emisji dwutlenku węgla?, Czy sa realizowane bądź planowane działania związane z gospodarką niskoemisyjną?, Czy gmina oczekuje wsparcia, jeżeli tak, to jakiego rodzaju, w zakresie uszczegółowienia pomiarów emisji?. Ponadto, gminy miały wymienić realizowane i planowane działania, jeśli takie istnieja. Zbiorcze zestawienie odpowiedzi znajduje się w tabeli 2.

TABELA 2. Identyfikacja zakresu działań gmin z Łódzkiego Obszaru Metropolitalnego w zakresie gospodarki niskoemisyjnej

\begin{tabular}{|c|c|c|c|c|c|c|}
\hline \multirow{2}{*}{ Nazwa gminy } & \multicolumn{2}{|c|}{ Pytanie 1. } & \multicolumn{2}{c|}{ Pytanie 2. } & \multicolumn{2}{c|}{ Pytanie 3. } \\
\cline { 2 - 7 } m. Brzeziny & TAK & NIE & TAK & NIE & TAK & NIE \\
Brzeziny & $\mathrm{x}$ & $\mathrm{X}$ & $\mathrm{x}$ & & $\mathrm{x}$ & \\
Andrespol & & $\mathrm{X}$ & $\mathrm{x}$ & $\mathrm{x}$ & - & - \\
Dmosin & & $\mathrm{X}$ & $\mathrm{x}$ & & $\mathrm{x}$ & \\
m. Koluszki & & $\mathrm{X}$ & $\mathrm{x}$ & & $\mathrm{x}$ & \\
Rzgów & & $\mathrm{X}$ & & $\mathrm{x}$ & & $\mathrm{x}$ \\
Nowosolna & & $\mathrm{X}$ & $\mathrm{x}$ & & $\mathrm{x}$ & \\
m. Tuszyn & $\mathrm{x}$ & & $\mathrm{x}$ & & $\mathrm{x}$ & \\
Lutomiersk & & $\mathrm{X}$ & $\mathrm{x}$ & & & $\mathrm{x}$ \\
Pabianice & & $\mathrm{X}$ & $\mathrm{x}$ & & & $\mathrm{x}$ \\
m. Pabianice & - & - & $\mathrm{x}$ & & - & - \\
Dłutów & & $\mathrm{X}$ & $\mathrm{x}$ & & $\mathrm{x}$ & \\
m. Ozorków & $\mathrm{x}$ & & $\mathrm{x}$ & & $\mathrm{x}$ & \\
Ozorków & & $\mathrm{X}$ & $\mathrm{x}$ & & & $\mathrm{x}$ \\
m. Zgierz & & $\mathrm{X}$ & $\mathrm{x}$ & & $\mathrm{x}$ & \\
Zgierz & & $\mathrm{X}$ & $\mathrm{x}$ & & - & - \\
Dobró́ & & $\mathrm{X}$ & & $\mathrm{x}$ & & $\mathrm{x}$ \\
Aleksandrów Lódzki & & $\mathrm{X}$ & - & - & - & - \\
Parzęczew & & $\mathrm{X}$ & $\mathrm{x}$ & & $\mathrm{x}$ & \\
Stryków & & $\mathrm{X}$ & $\mathrm{x}$ & & & $\mathrm{x}$ \\
m. Głowno & & $\mathrm{X}$ & & $\mathrm{x}$ & & $\mathrm{x}$ \\
m. Lódź & & $\mathrm{X}$ & $\mathrm{x}$ & & & $\mathrm{x}$ \\
\hline
\end{tabular}

Źródło: opracowanie własne na podstawie przesłanych materiałów z jednostek samorządu terytorialnego $\mathrm{LOM}$. 
Jak wynika z treści tabeli 2., badane gminy wykazuja bardzo zróżnicowane zainteresowanie kwestią rozwoju gospodarki niskoemisyjnej na swoim terenie. Zaledwie trzy spośród 22 gmin, które wzięły aktywny udział w badaniu, odpowiedziały twierdząco na pytanie o rozpoznanie poziomu i źródeł emisji $\mathrm{CO}_{2}$ na swoim terenie. Większość gmin (16) planuje takie działania i oczekuje w związku z tym wsparcia finansowego z zewnątrz (8 gmin). Cztery gminy nie podjęły i nie planuja podjęcia żadnej aktywności w zakresie rozwoju gospodarki niskoemisyjnej.

Spośród gmin, które nadesłały odpowiedzi na pytania ankietowe, najczęściej realizowaną formą działania jest termomodernizacja obiektów użyteczności publicznej (9 wskazań). Wymieniono również inwestycje związane z: instalacją kolektorów słonecznych, ogniw fotowoltaicznych i pomp ciepła, rozwojem miejskiego systemu ciepłowniczego (3 wskazania) i budowa instalacji gazowej [Dokument elektroniczny, tryb dostępu: http://www.uml.lodz.pl/miasto/strategia/strategia_rozwoju_lodzkiego_obszaru_metropolitalnego, data wejścia: 05.06.2014].

Obserwacje poczynione w związku z realizacja badania na potrzeby opracowania Strategii Rozwoju Lódzkiego Obszaru Metropolitalnego 2020+ w odniesieniu do gospodarki niskoemisyjnej, świadczące o generalnie wciąż słabej znajomości problemu, są zbieżne z wynikami badania pt.: Polacy o oszczedzaniu energii [Dokument elektroniczny, tryb dostępu: http://6paliwo.pl/wp-content/uploads/2012/02/6paliwo-raport-1.pdf, data wejścia: 06.06.2014]. Aż 82\% respondentów nie wiedziało, że najwięcej energii zużywa się na eksploatację budynków, mylnie wskazując na przemysł. Zaledwie 4\% respondentów zdawało sobie sprawę z tego, że $70 \%$ energii w gospodarstwach domowych pochłania ogrzewanie i upatrywało największe możliwości oszczędzania energii $\mathrm{w}$ korzystaniu z oświetlenia. Tymczasem w Polsce termomodernizacja wszystkich budynków mieszkalnych pozwoliłaby zaoszczędzić około $10 \mathrm{mln}$ ton węgla [Techniczne i ekonomiczne aspekty ocieplania budynkón, 2006.]

\section{Ewidencjonowanie danych na potrzeby planowania gospodarki niskoemisyjnej}

Generalnie, można stwierdzić, że dotychczas samorządy lokalne nie były zainteresowane gromadzeniem i dalszą analizą danych dotyczących emisji z podziałem na rodzaje i źródła pochodzenia zanieczyszczeń. Dane zbiorcze, publikowane przez Główny Urząd Statystyczny w rocznikach Ochrona środowiska, związane z emisją zanieczyszczeń gazowych, odprowadzonych przez jednostkę sprawozdawczą do atmosfery w ciagu roku, obejmuja: dwutlenek siarki, tlenki azotu (wyrażone w dwutlenku azotu - $\mathrm{NO}_{2}$ ), tlenek węgla, dwutlenek węgla (od 1993 roku), węglowodory i inne emitowane przez dany zakład zanieczyszczenia gazowe, określone w rozporządzeniu Rady Ministrów w sprawie opłat za korzystanie ze środowiska. Wielkość emisji zanieczyszczeń pyłowych oraz dwutlenku siarki zazwyczaj jest ustalana metodami pomiarowymi, a w przypadku braku urządzeń pomiarowych dokonuje się oszacowania wielkości emisji. Wielkości emisji pozostałych rodzajów zanieczyszczeń gazowych opierają się przeważnie na ustaleniach szacunkowych. Wskaźnik wykorzystywany w rocznikach Ochrona środowiska, dotyczący 
stopnia redukcji zanieczyszczeń gazowych, został wyliczony i przedstawiony bez uwzględnienia wielkości emisji $\mathrm{CO}_{2}$, z uwagi na to, że ta charakteryzuje się dużymi wartościami bezwzględnymi. Jednolita metodologia określania emisji poszczególnych rodzajów zanieczyszczeń i w miarę stabilna w kolejnych latach zbiorowość zakładów pozwala na ogólną ocenę skali zjawisk oraz tendencji i dynamiki zmian zagrożenia atmosfery ze strony głównych, przemysłowych i energetycznych źródeł zanieczyszczeń powietrza [Ochrona środoniska, 2013]. Tak wysoki stopień agregacji danych, a także odrębne traktowanie emisji $\mathrm{CO}_{2}$ czyni je nieprzydatnymi dla potrzeb rozwoju gospodarki niskoemisyjnej przez JST.

Dane BDL również są niewystarczające, jeżeli chodzi o konieczność budowy strategii gospodarki niskoemisyjnej na poziomie JST. Na przykład zawieraja pewne informacje na temat liczby termomodernizowanych budynków, ale bez podania zmian w emisji gazów cieplarnianych.

Z punktu widzenia budowy strategii gospodarki niskoemisyjnej przez JST niewiele bardziej użyteczne są dane gromadzone i publikowane przez wojewódzkie inspektoraty ochrony środowiska. W tym przypadku także należy stwierdzić istnienie istotnych ograniczeń wynikających głównie z przedmiotu ewidencji. Oceny jakości powietrza dokonuje się oddzielnie, uwzględniając kryteria ustanowione ze względu na ochronę zdrowia ludzi oraz kryteria ustalone $\mathrm{z}$ uwagi na ochronę roślin. Ocena obejmuje wszystkie substancje ujęte w Rosporzadzeniu Ministra Środowiska z dnia 3 marca 2008 roku w sprawie poziomón niektórych substancï w pownietrzu oraz ponadto pył drobny PM2,5 (zgodnie z projektem nowelizacji ustawy Prawo ochrony środowiska oraz zaleceniami Ministra Środowiska i wytycznymi GIOŚ).

Lista zanieczyszczeń, jakie należy uwzględnić $\mathrm{w}$ ocenie dokonywanej pod kątem spełnienia kryteriów określonych w celu ochrony zdrowia, zawiera: benzen $\mathrm{C}_{6} \mathrm{H}_{6}$, dwutlenek azotu $\mathrm{NO}_{2}$, dwutlenek siarki $\mathrm{SO}_{2}$, tlenek węgla $\mathrm{CO}$, ozon $\mathrm{O}_{3}$, pył PM2,5, pył PM10, ołów $\mathrm{Pb}$ w pyle PM10, arsen As w pyle PM10, kadm Cd w pyle PM10, nikiel Ni w pyle PM10, benzo(a)piren w pyle PM10. Ponadto, sa publikowane dane, które należy uwzględnić w ocenie rocznej, dokonywanej pod względem spełnienia kryteriów określonych w celu ochrony roślin. Obejmuja one: dwutlenek siarki $\mathrm{SO}_{2}$, tlenki azotu $\mathrm{NO}_{\mathrm{x}}$, ozon $\mathrm{O}_{3}$. Zarówno dane ewidencjonowane $\mathrm{z}$ uwagi na ochronę zdrowia, jak ochronę roślin nie sa, generalnie, przydatne do budowy strategii gospodarki niskoemisyjnej przez samorządy lokalne. Jednak można stwierdzić, że główne zagrożenia pochodzą ze spalania paliw kopalnych, stąd zmiana profilu energetycznego gmin może także znacząco wpłynąć na poprawę stanu powietrza. Emisje i obecność w powietrzu, wyżej wymienionych, substancji jest monitorowana ze względu na konieczność przestrzegania zapisów szeregu regulacji Unii Europejskiej i krajowych.

Na mocy ustawy Prawo ochrony środowiska (art. 89) wojewódzcy inspektorzy ochrony środowiska co roku, w terminie do dnia 31 marca każdego roku, dokonują oceny poziomów substancji w powietrzu w danej strefie za rok poprzedni oraz odrębnie dla każdej substancji klasyfikacji stref, w których poziom odpowiednio: 1) przekracza poziom dopuszczalny, powiększony o margines tolerancji; 2) mieści się pomiędzy poziomem dopuszczalnym a poziomem dopuszczalnym powiększonym o margines tolerancji; 3) nie przekracza poziomu dopuszczalnego; 4) przekracza poziom docelowy; 
5) nie przekracza poziomu docelowego; 6) przekracza poziom celu długoterminowego; 7) nie przekracza poziomu celu długoterminowego. Roczną ocenę jakości powietrza sporządza się na podstawie przyjętych kryteriów, tj.: dopuszczalnego poziomu substancji w powietrzu, poziomu dopuszczalnego, powiększonego o margines tolerancji, poziomu docelowego oraz poziomu celu długoterminowego, określonego w Rozporradzeniu Ministra Środowiska z. dnia 3 marca 2008 roku w sprawie poziomón niektórych substancji w powietrzu [Rosporzadzeniu Ministra Środowiska z. dnia 3 marca 2008 roku..., 2008]. Ocena i odpowiednia klasyfikacja jakości powietrza jest niezwykle istotna z punktu widzenia planowania działań na rzecz poprawy jakości powietrza w danej strefie. Dodatkowym celem rocznej oceny jakości powietrza jest uzyskanie informacji o przestrzennych rozkładach wartości stężenia zanieczyszczeń na obszarze aglomeracji lub innej strefy, w zakresie umożliwiającym wskazanie obszarów przekroczeń wartości kryterialnych, oraz określenie poziomów stężenia występujących na tych obszarach. Informacje te mogą być pomocne także w ustalaniu przyczyn występowania ponadnormatywnych stężeń zanieczyszczeń w określonych rejonach, co może stanowić punkt wyjścia działań naprawczych. Mimo to, trzeba zdawać sobie sprawę z tego, że wiele zanieczyszczeń powietrza migruje niekiedy na dalekie odległości, przekraczając granice JST i uniemożliwiając samorządom lokalnym skuteczne przeciwdziałanie powstawaniu emisji. Wskazanie źródeł lub grup źródeł emisji odpowiedzialnych za zanieczyszczenie powietrza $\mathrm{w}$ danym rejonie często wymaga przeprowadzenia złożonych analiz, $\mathrm{z}$ wykorzystaniem obliczeń za pomocą modeli matematycznych.

Roczne, pięcioletnie jak i wstępne oceny jakości powietrza są dokonywane dla stref oceny. W związku z wejściem w życie dyrektywy CAFE (2008/50/WE), od 2010 roku są to obszary:

- $\quad$ aglomeracji o liczbie mieszkańców powyżej 250 tys.;

- $\quad$ miasta o liczbie mieszkańców powyżej 100 tys.;

- pozostałe obszary województwa.

Właściwie przedmiotem zainteresowania samorząóo powinna pozostawać emisja antropogeniczna, którą można skutecznie zarządzać z poziomu danej JST. W emisji antropogenicznej wyróżnia się:

- emisje punktowe pochodzące ze zorganizowanych źródeł w wyniku energetycznego spalania paliw i przemysłowych procesów technologicznych;

- emisje liniowe - komunikacyjne, pochodzące głównie z: transportu samochodowego, kolejowego, wodnego i lotniczego;

- $\quad$ emisje powierzchniowe, w skład których wchodzą zanieczyszczenia komunalne z palenisk domowych, gromadzenia i utylizacji ścieków i odpadów;

- emisję z rolnictwa pochodzącą z upraw i hodowli zwierząt;

- emisję niezorganizowana, powstająca wskutek: pojedynczych pożarów, prac budowlanych i remontowych, nakładania na powierzchnie warstw kryjących, przypadkowych wycieków itp.

Samorządy, przystępując do sporządzenia bazowej inwentaryzacji emisji, mają za zadanie wyliczenie ilości $\mathrm{CO}_{2}$ wyemitowanego w wyniku zużycia energii na terenie miasta lub gminy w roku bazowym. Pozwala to na zidentyfikowanie głównych antropogenicznych źródeł emisji $\mathrm{CO}_{2}$ oraz odpowiednie zaplanowanie i uszeregowanie pod wzglę- 
dem ważności środków jej redukcji. Władze lokalne mogą uwzględnić w inwentaryzacji także emisje $\mathrm{CH}_{4}$ oraz $\mathrm{N}_{2} \mathrm{O}$. Bazowa inwentaryzacja emisji ma stanowić instrument umożliwiający władzom lokalnym pomiar efektów zrealizowanych przez nie działań związanych z ochroną klimatu, jak również służyć śledzeniu zmian w zakresie realizacji przyjętego celu redukcyjnego i ocenie efektów. W tym celu powinno się stosować odpowiednio dobrane wskaźniki. Na przykład mogą to być:

- ilość $\mathrm{CO}_{2}$ wyemitowanego na każdą MWh zużytego oleju [ $\mathrm{t} \mathrm{CO}_{2} / \mathrm{MWhfuel];}$

- $\quad$ ilość $\mathrm{CO}_{2}$ wyemitowanego na każdą MWh zużytej energii elektrycznej [t CO2/ MWhe];

- $\quad$ ilość $\mathrm{CO}_{2}$ wyemitowanego na każdą MWh zużytej energii cieplnej [t CO2/ MWhheat].

Rekomenduje się sporządzanie inwentaryzacji emisji $\mathrm{CO}_{2}$ na podstawie końcowego zużycia energii na terenie miasta/gminy, zarówno w sektorze komunalnym, jak i pozakomunalnym:

1. emisje bezpośrednie ze spalania paliw w budynkach, instalacjach oraz sektorze transportu;

2. emisje pośrednie, towarzyszące produkcji: energii elektrycznej, ciepła i chłodu, wykorzystywanej przez odbiorców końcowych, zlokalizowanych na terenie miasta/gminy;

3. pozostałe emisje bezpośrednie, występujące na terenie miasta/gminy.

Punkty: 1. i 3. dotyczą emisji, które fizycznie występują na terenie miasta/gminy. Ich uwzględnienie jest zgodne z zasadami IPCC, stosowanymi przez kraje, które są sygnatariuszami Ramowej Konwencji Narodów Zjednoczonych w sprawie Zmian Klimatu (UNFCCC). Natomiast punkt 2. obejmuje emisje, które powstają w związku z produkcja: energii elektrycznej, ciepła i chłodu, wykorzystywaną na terenie miasta/gminy. Ujmuje się je niezależnie od lokalizacji zakładów wytwarzających wymienione nośniki energii (w granicach lub poza granicami miasta/gminy).

\section{Podsumowanie}

W Unii Europejskiej działanie na rzecz gospodarki niskoemisyjnej jest integralna częścią pakietu klimatyczno-energetycznego, Strategii Europa 2020 i Planu driatania prowadzacego do przejśsia na konkurencyjna gospodarke niskoemisyjna do 2050 roku. Polska dość opieszale wdraża do krajowego systemu legislacyjnego ustawy będące transpozycją unijnych przepisów. Wpływa to także na zachowanie samorządów terytorialnych. Nadal władze samorządowe w Polsce tylko w niewielkim stopniu traktuja rozwój gospodarki niskoemisyjnej jako istotne wyzwanie dotyczące przyszłości.

Biorąc pod uwagę rekomendowane kierunki wydatkowania środków z funduszy europejskich, można stwierdzić, że rozwój gospodarki niskoemisyjnej został zaliczony do działań priorytetowych. Oznacza to, że samorządy lokalne stoją przed nowym wyzwaniem związanym $\mathrm{z}$ budowaniem własnych planów zaopatrzenia w energię, obejmujacych działania, które mają służyć redukcji emisji gazów cieplarnianych, a przy tej okazji również szeregu innych zanieczyszczeń powietrza. Gospodarka niskoemisyjna bazuje 
bowiem na termomodernizacji, odnawialnych źródłach energii i transporcie przyjaznym dla środowiska. Podstawowe trudności, jakie mogą napotkać samorządy w związku z przechodzeniem do gospodarki niskoemisyjnej, to:

- brak szczegółowych danych źródłowych na temat wielkości emisji $\mathrm{CO}_{2}$ i ewentualnie także innych gazów cieplarnianych, pochodzących z poszczególnych obiektów/obszarów;

- brak odpowiednio wykształconych kadr zarówno w zakresie monitoringu emisji, jak i zarządzania energia na poziomie JST;

- brak szerszego, społecznego poparcia dla tego typu działań, wynikający głównie z dość niskiego poziomu świadomości energetycznej Polaków;

- brak środków finansowych (lub ich ograniczoność) na: prowadzenie pomiarów, ewidencjonowanie danych i zarządzanie bazami danych istotnych z punktu widzenia budowy gospodarki niskoemisyjnej;

- brak środków finansowych na odpowiednie działania inwestycyjne i nieinwestycyjne.

Reasumując, analiza dostępnych danych statystycznych w zakresie emisji gazów cieplarnianych pozwala stwierdzić, że podobnie dostępność, jak i jakość danych pozostawiają bardzo wiele do życzenia. Wynika to w pewnej mierze z niedostatecznego zainteresowania budowa gospodarki niskoemisyjnej z uwagi na wciąż ogromne znaczenie energii pochodzącej ze spalania węgla w polskim „miksie” energetycznym. Narzucenie samorządom lokalnym kolejnych zadań powinno iść w parze $z$ przekazaniem im do dyspozycji odpowiednich środków finansowych i ze wsparciem merytorycznym na wykonanie podstawowych inwentaryzacji emisji. Brak doświadczeń z tym związanych powoduje uzasadnione obawy dotyczące nowego zadania.

\section{Literatura}

Budowa gospodarki niskoemisyjnej. Podrecznik dla regionów, INTERREG IVC, dokument elektroniczny, tryb dostępu: [http://documents.rec.org/publications/RSC_BuildingLow_carbonEconomy_PL_Dec2011.pdf, data wejścia: 15.01.2014].

Dyrektywa Parlamentu Europejskiego i Rady 2009/125/WE z dnia 21 paźdriernika 2009 roku ustanawiajaca ogólne zasady ustalania wymogón dotyczacych ekoprojektu dla produktón zwiazanych z energia (wersja przekształcona).

Dyrek.tywa Parlamentu Europejskiego i Rady z. dnia 21 maja 2008 roku (2008)/50/WE w sprawie jakości powietrza i crystszego powietrza dla Europy CAFE.

Hong A. C., Young C. J., Hurley M. D., Wallington T. J., Mabury S. A. 2013 Geophysical Research Letters Issue, vol. 40, Issue 22, 28 November.

Komunikat Komisji dla Rady, Parlamentu Europejskiego, Europejskiego Komitetu Ekonomiczno-Spotecznego i Komitetu Regionów. Promowanie zrównoważonego wykeraystania zasobów: Strategia tematyczna w sprawie zapobiegania powstawaniu odpadów $i$ ich recyklingu, Bruksela, dnia 21.12.2005 COM(2005) 666 końcowy.

Komunikat Komisji dla Rady, Parlamentu Europejskiego, Europejskiego Komitetu Ekonomiczno-Spotecznego $i$ Komitetu Regionów. Plan dzৃiałania prowadzacy do przejścia na konkuren- 
cyjna gospodarke niskoemisyjna do 2050 roku, Bruksela, dnia 08.03.2011 KOM(2011) 112, wersja ostateczna.

Norma ISO 14040:2006, Environmental management - Life cycle assessment - Principles and Framework.

Ochrona środowiska 2013 GUS, Warszawa.

Rozporzadzenie Komisji (UE) 82/2013 z. dnia 14 sierpnia 2013 roku zmieniajace załacznile III do rozporzadzenia Parlamentu Europejskiego i Rady (UE) 6/2010 w sprawie oznakowania ekologicznego UE.

Polacy o oszcrzedzaniu energï, dokument elektroniczny, tryb dostępu: [http://6paliwo.pl/ wp-content/uploads/2012/02/6paliwo-raport-1.pdf, data wejścia: 06.06.2014].

Rozporzqdzenie Komisji (UE) nr 782/2013 z dnia 14 sierpnia 2013 roku zmieniajace zatacznik III do rozporzadzenia Parlamentu Europejskiego $i$ Rady (UE) nr 66/2010 w sprawie oznakowania ekologicznego.

Rozporz̨qdzeniu Ministra Środowiska z dnia 3 marca 2008 roku w sprawie poziomów niektórych substancji w powietrzu, Dz. U., 2008, Nr 47, poz. 281.

SEAP, Poradnik: Jak opracować plan dzৃałań na rzecz, zrównoważonej energiii? 2012, European Commission, Institute for Energy, Luxemburg 2010, wydanie polskie 2012. Strategia Rožvoju Lódzৃkiego Obszaru Metropolitalnego 2020+, dokument elektroniczny, tryb dostępu: [http://www.uml.lodz.pl/miasto/strategia/strategia_rozwoju_lodzkiego _obszaru_metropolitalneg, data wejścia: 05.06.2014].

Tecbniczne i ekonomiczne aspekty ocieplania budynków 2006, ITB, Warszawa 2006.

Ustawa Prawo ochrony środowiska, Dz. U., 2001, Nr 62, poz. 627.

Ustawa z dnia 10 kwietnia 1997 roku, Prawo energetyczne, tekst jednolity, Dz. U., 2008, $\mathrm{Nr} 89$, poz. 625.

Ustawa z. dnia 15 knietnia 2011 roku o efektywności energetycznej, Dz. U., Nr 94, poz. 551. Zatożenia narodowego planu rožjoju gospodarki niskoemisyjnej 2011, Rada Ministrów, Warszawa. 